\title{
PENGARUH APLIKASI PESTISIDA TERHADAP BAKTERI Pseudomonas spp. SEBAGAI PENGURAI BAHAN ORGANIK PADA TANAH GAMBUT
}

\author{
Brata Pantjara ${ }^{*}$, Akhmad Mustafa*', Adi Hanafi*', dan Muliani*)
}

\begin{abstract}
ABSTRAK
Pada tanah gambut didapatkan bakteri pengurai bahan organik yang dominan yaitu Pseudomonas spp., tetapi penggunaan pestisida oleh petambak diduga dapat mengurangi kinerja bakteri tersebut. Untuk itu dilakukan penelitian yang bertujuan mengetahui daya hambat dan toksisitas pestisida terhadap mikroba pengurai serta pengaruhnya terhadap kualitas tanah gambut. Penelitian dilakukan pada skala laboratorium dengan menggunakan media TSA (Tryptic Soy Agar) dan paperdisk ( $13 \mathrm{~mm}$ ) untuk uji daya hambat, sedangkan uji toksisitas menggunakan media NB (Nutrient Broth) dan tanah gambut untuk uji toksisitas bakteri. Bakteri yang diuji adalah Pseudomonas spp. merupakan hasil kultur murni yang diisolasi dari tanah gambut dan diaplikasikan dengan kepadatan $10^{6} \mathrm{CFU} / \mathrm{mL}$ pada media NB dan $10^{6} \mathrm{CFU} / \mathrm{g}$ tanah kering pada media tanah gambut. Tiga jenis pestisida yang diuji adalah Brestan, Thiodan dan Hostathion dengan konsentrasi 0,$001 ; 0,01 ; 0,1 ; 1,0$ dan 10,0 mg/L serta kontrol masing-masing tiga ulangan yang disusun berdasarkan rancangan acak lengkap untuk setiap jenis pestisida. Diameter hambatan pada konsentrasi tertinggi $(10,0 \mathrm{mg} / \mathrm{L})$ yaitu: $18,78,4,58$, dan $9,9 \mathrm{~mm}$ berturut-turut pada Brestan, Thiodan dan Hostathion. Brestan menghambat perkembangan Pseudomonas spp. pada konsentrasi terendah 0,01 mg/L, sedangkan Thiodan dan Hostathion pada konsentrasi $1,0 \mathrm{mg} / \mathrm{L}$. Daya hambat tertinggi adalah Brestan. Uji toksisitas menunjukkan populasi Pseudomonas spp. menurun dengan kenaikan konsentrasi uji. Toksisitas tertinggi adalah Thiodan pada media NB dan Hostathion pada media tanah gambut.
\end{abstract}

\begin{abstract}
Effect of pesticide on decomposer bacteria Pseudomonas spp. organic matter in peat soil. By: Brata Pantjara, Akhmad Mustafa, Adi Hanafi, and Muliani.

One of the dominant organic matter decomposes identified from peat soil was Pseudomonas spp. It is believed that the application of pesticides affects the population of Pseudomonas spp. The aim of this experiment was to determine the intensity of pesticides inhibition, effect on the population of Pseudomonas spp. and change of peat soil quality. The experiment was conducted under laboratory condition using TSA (Tryptic Soy Agar) media and paperdisk of $13 \mathrm{~mm}$ in diameter for inhibition test. While toxicity tests were conducted in pure NB (Nutrient Broth) and peat soil. The population of Pseudomonas spp. tested was $10^{6} \mathrm{CFU} / \mathrm{mL}$ in $\mathrm{NB}$ and $10^{6}$ CFU/g dry soil in peat soil. The three pesticides tested were Brestan, Thiodan and Hostathion with concentration treatments of $0.001 ; 0.01 ; 0.1 ; 1.0 ; 10 \mathrm{mg} / L$ and control with three replicates following the completely randomized design. The inhibition diametres at $10.0 \mathrm{mg} / \mathrm{L}$ was 18.78 , 4.58 , and $9.9 \mathrm{~mm}$ for Brestan. Thiodan and Hostathion respectively. Brestan inhibited up to concentration of $0.01 \mathrm{mg} / \mathrm{L}$, while Thiodan and Hostathion at concentration of $1.0 \mathrm{mg} / \mathrm{L}$. The highest inhibition zone was Brestan. Toxicity test showed that the Pseudomonas spp. population tend to decrease with higher concentration. The highest toxicity was Thiodan in NB media and Hostathion in peat soil media.
\end{abstract}

KEYWORDS: pesticide, bacteria, organic matter, peat soil.

\section{PENDAHULUAN}

Kandungan serasah (berasal dari hancuran bagian tumbuhan) pada tanah gambut yang sangat tinggi menyebabkan kandungan bahan organik di tanah cukup tinggi (C-organik $>12 \%$ ). Bahan organik selanjutnya menjadi asam-asam organik yang bereaksi masam dan menyebabkan menurunnya produktivitas tanah. Di samping itu ketidakmampuan mikroba dalam mendekom. posisikan bahan organik yang tersedia di tanah menyebabkan pula kualitas tanah gambut menjadi rendah.

Mikroba tanah berperan merombak bahan organik sehingga dapat mempercepat proses

\footnotetext{
*) Peneliti pada Balai Penelitian Perikanan Pantai, Maros
} 
pematangan tanah dan diharapkan akan meningkatkan produktivitas primer atau pertumbuhan jasad makanan alami. Aktivitas mikroba di. pengaruhi oleh kandungan bahan organik tanah dan rasio $\mathrm{C}: \mathrm{N}$ serta keasaman tanah, sehingga perlu diciptakan kondisi yang dapat meningkatkan kinerja mikroorganisme pengurai tersebut. Nilai nutrisi media sangat menentukan pertumbuhan dari mikroba. Kebutuhan dasar mikroba umumnya meliputi: air, karbon, energi, nitrogen, mineral, dan faktor pertumbuhan (Benson, 1985; Moriarty, 1987). Pada $\mathrm{pH}$ tanah yang rendah jamur lebih aktif dibandingkan dengan bakteri dalam menguraikan bahan organik (Garret, 1981). Pada rasio C:N antara $10 \cdot 15$, mikroba pengurai bahan organik akan bekerja lebih aktif daripada rasio C:N yang lebih tinggi (Boyd, 1992).

Mikroba pengurai bahan organik pada dasarnya tersedia secara alami dan kemampuan penguraiannya dipengaruhi oleh jenis substrat dan kondisi tanah. Pada tanah gambut yang berbeda dijumpai mikroba pengurai bahan organik dominan yang berbeda pula. Berdasarkan hasil penelitian Pantjara et al. (1997a) yang dilakukan di beberapa Kabupaten di Sulawesi Selatan teridentifikasi 12 genera bakteri, delapan di antaranya tergolong bakteri pengurai bahan organik di mana salah satunya terdapat bakteri Pseudomonas spp. Hanafi et al. (1995) juga telah menemukan bakteri Cytophaga spp. di kawasan mangrove di Kabupaten Sinjai, Sulawesi Selatan. Menurut Winogradsky (dálam Sutedjo et al., 1991) Cytophaga spp. termasuk bakteri pengurai bahan organik secara umum (selulosa secara khusus) selain genera Cellvibrio dan Cellfalcicula.

Penggunaan berbagai pestisida pada proses persiapan budidaya udang sering dilakukan oleh petani tambak, di mana petani tambak menggunakan pestisida dengan dosis yang berlebih tanpa memperhatikan dampak negatif terhadap organisme lain bukan sasaran. Di samping itu penggunaan pestisida yang terus-menerus di tambak dapat menimbulkan meningkatnya residu bahan aktif dari pestisida (buprofezin, trifenil asetat, endosulfan, triazofos dan bahan aktif lainnya) pada tanah, sehingga dapat mengarah pada ketidakseimbangan tatanan ekologi. Penggunaan pestisida Brestan, Thiodan dan Hostathion oleh petani tambak untuk memberantas ikan liar dan trisipan di tambak diduga dapat membunuh mikroba pengurai bahan organik di tanah. Tujuan penelitian untuk mengetahui pengaruh pestisida terhadap daya tahan bakteri pengurai bahan organik tambak tanah gambut.

\section{BAHAN DAN METODE}

Penelitian dilakukan di Laboratorium Balai Penelitian Perikanan Pantai, Maros dari bulan Juli sampai dengan Oktober 1997. Pestisida yang dipilih adalah jenis pestisida yang sering digunakan petani pada persiapan tambak sebelum budidaya yaitu Brestan, Thiodan dan Hostathion. Masing-masing jenis pestisida mengandung bahan aktif sebagai berikut: Brestan $56,4 \%$ timah trifenil asetat dan $15,75 \%$ maneb, Thiodan $35,2 \%$ endosulfan dan Hostathion $42,0 \%$ triazofos.

Penelitian dilakukan dalam dua tahap yaitu uji pendahuluan untuk menguji daya hambat bakteri dan uji toksisitas untuk mengetahui pengaruh pestisida terhadap populasi bakteri Pseudomonas spp.

\section{Uji Daya Hambat}

Untuk uji daya hambat dicobakan konsentrasi pestisida: 0,$0001 ; 0,001 ; 0,01 ; 0,1 ; 1,0 ;$ dan 10,0 $\mathrm{mg} / \mathrm{L}$; serta tanpa pestisida sebagai kontrol, masing-masing dengan enam ulangan yang disusun berdasarkan rancangan acak lengkap untuk setiap jenis pestisida. Media yang digunakan adalah TSA (Tryptic Soy Agar) dalam cawan petri yang berisikan paperdisk (diameter $=13 \mathrm{~mm}$ ). Biakan murni bakteri Pseudomonas spp. yang diisolasi berasal dari tanah gambut dan diinokulasi ke dalam media TSA pada cawan petri dengan kepadatan $10^{6} \mathrm{CFU} / \mathrm{mL}$. Paperdisk dicelupkan ke dalam pestisida yang telah ditentukan konsentrasinya sampai jenuh, kemudian dimasukkan ke dalam TSA dalam cawan petri yang telah diinokulasi dengan bakteri Pseudomonas spp. dan selanjutnya diinkubasi selama 48 jam pada suhu $25^{\circ} \mathrm{C}$. Pengamatan daya hambat dilakukan dengan mengukur diameter hambatan $(\mathrm{mm})$ pada media TSA menggunakan penggaris Dial Califer (mistar geser) dengan tingkat ketelitian alat ukur $\pm 0,1 \mathrm{~mm}$. Pengukuran diameter dilakukan minimal sebanyak 4 kali tergantung lingkaran hambatan. Semakin kurang beraturan bentuk lingkaran semakin banyak ulangan pengukuran. Data yang diperoleh dianalisis ragam dengan rancangan acak lengkap dengan terlebih dahulu ditransformasi dalam bentuk transformasi $\mathrm{x}+1 / 2$ mengikuti petunjuk Gaspersz (1992). 


\section{Uji Toksisitas}

Untuk uji toksisitas digunakan dua media yaitu NB (Nutrient Broth) dan tanah gambut, dengan konsentrasi pestisida adalah 0,$001 ; 0,01$; 0,$1 ; 1,0 ; 10 \mathrm{mg} / \mathrm{L}$, dan tanpa pestisida sebagai kontrol, masing-masing diulang tiga kali yang disusun berdasarkan rancangan acak lengkap untuk setiap jenis pestisida. Biakan murni bakteri Pseudomonas spp. ditumbuhkan pada media NB dengan kepadatan bakteri $10^{6} \mathrm{CFU} / \mathrm{mL}$. Selanjutnya pada biakan bakteri tersebut diaplikasikan pestisida Brestan, Thiodan dan Hostathion sesuai konsentrasi, kemudian diinkubasi pada suhu $25^{\circ} \mathrm{C}$. Perkembangan populasi bakteri Pseudomonas spp. diamati pada hari ke-3, 6, 9, 12, dan 15 .

Pada media tanah gambut, tanah tersebut sudah dibersihkan dari serasah yang kasar dan disterilkan dalam autoclave pada suhu $121^{\circ} \mathrm{C}$ dan tekanan 1 atm selama dua jam dengan tujuan membunuh semua mikroba di dalam tanah. Tanah gambut dengan kadar air 56,48\% ditimbang dengan bobot $177 \mathrm{~g}$ atau setara dengan $100 \mathrm{~g}$ bobot kering pada gelas piala $500 \mathrm{~mL}$ dan disimpan ke dalam cleanbench. Bakteri Pseudomonas spp. hasil biakan murni kemudian diaplikasikan ke dalam tanah gambut dengan kepadatan bakteri $10^{6} \mathrm{CFU} /$ g kering tanah. Pengamatan perkembangan populasi bakteri dilakukan pada hari ke-3, 6, 9, 12 , dan 15 dengan mengambil $1 \mathrm{~g}$ tanah kemudian diencerkan ke dalam $9 \mathrm{~mL}$ larutan $\mathrm{NaCl} 0,85 \%$.

Pengenceran dilakukan secara bertingkat $\left(10^{-4}\right.$; $\left.10^{-5} ; 10^{-6} ; 10^{-7}\right)$, kemudian diinokulasi ke dalam me- dia TSA dalam cawan petri. Populasi bakteri dihitung dengan metode pengenceran menurut Standar Plate Count (Lay, 1994).

Pengamatan kualitas tanah meliputi $\mathrm{pH}$, potensial redoks, bahan organik, $\mathrm{N}$ total, dan rasio C:N dilakukan pada awal dan akhir penelitian. Data yang diperoleh dianalisis ragam dengan rancangan acak lengkap.

\section{HASIL DAN PEMBAHASAN}

\section{Uji Daya Hambat}

Introduksi pestisida pada paperdisk ke dalam media TSA yang diberi biakan murni bakteri Pseudomonas spp. menunjukkan adanya daya hambat terhadap pertumbuhan bakteri. Uji daya hambat pestisida Brestan, Thiodan, dan Hostathion disajikan pada Gambar 1. Dari hasil uji terlihat bahwa pengaruh pestisida (Brestan, Thiodan, Hostathion) dengan berbagai konsentrasi pada media TSA menunjukkan tingkat daya hambat yang berbeda.

Pestisida Brestan mempunyai daya hambat yang paling tinggi terhadap bakteri Pseudomonas spp. dengan diameter hambatan 18,$78 ; 13,12 ; 8,76$; dan $6,36 \mathrm{~mm}$ (luas hambatan $=666,407,239$, dan 161 $\mathrm{mm}^{2)}$ pada konsentrasi pestisida 10,$0 ; 1,0 ; 0,1$; dan 0,01 mg/L, sedangkan Thiodan sebesar 4,58 dan 4,15 mm (luas hambatan $=132$ dan $100 \mathrm{~mm}^{2}$ ) pada konsentrasi masing-masing 10,0 dan $1,0 \mathrm{mg} / \mathrm{L}$ dan Hostathion sebesar 9,9 dan $4,83 \mathrm{~mm}$ (luas hambatan $=213 \mathrm{dan} 118 \mathrm{~mm}$ ) masing-masing untuk konsentrasi 10,0 dan 1,0 mg/L (Lampiran 1).

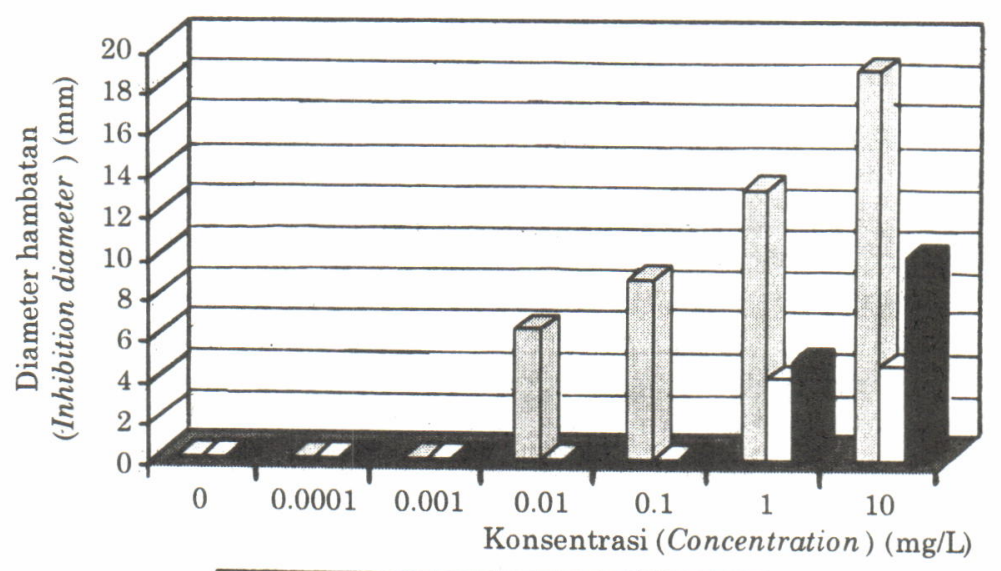

$\square$ Brestan $\square$ Thiodan Hostathion

Gambar 1. Diameter hambatan berbagai pestisida dalam media TSA.

Figure 1. Inhibition diameter of different pesticides on TSA media. 
Konsentrasi pestisida yang diberikan mampu menghambat pertumbuhan bakteri Pseudomonas spp. untuk masa inkubasi dua hari, di mana Pseudomonas spp. yang diaplikasikan di antara isolat penghambat tidak dapat berkembang dan secara nyata dapat dibedakan dengan konsentrasi yang lebih rendah dari masing-masing pestisida. Hal ini terlihat dari bakteri yang tumbuh di media TSA. Tingginya daya hambat dari Brestan diduga karena pestisida ini mengandung bahan aktif yang lebih toksik untuk menghambat perkembangan bakteri Pseudomonas spp. daripada bahan aktif yang terkandung dalam Thiodan dan Hostathion.

\section{Uji Toksisitas}

Hasil penelitian menunjukkan bahwa bakteri Pseudomonas spp. pada media NB dapat hidup dan berkembang biak sampai konsentrasi $10,0 \mathrm{mg} / \mathrm{L}$ pada semua jenis pestisida yang dicobakan. Secara umum tidak terjadi adanya kecenderungan perubahan populasi Pseudomonas spp. baik terhadap waktu pengamatan maupun terhadap konsentrasi uji (Lampiran 2). Akan tetapi, dari ketiga pestisida memberikan indikasi bahwa pestisida Thiodan memberikan daya racun yang lebih tinggi dibandingkan dengan pestisida Brestan dan Hostathion, di mana populasi bakteri Pseudomonas spp. paling rendah pada setiap pengamatan sejak hari ke- 6 hingga ke-15 pada media.

Selama penelitian berlangsung belum ditemukan bakteri mati total pada jenis dan konsentrasi pestisida yang berbeda. Hal ini menunjukkan bahwa konsentrasi pestisida (Brestan, Thiodan dan Hostathion) $10,0 \mathrm{mg} / \mathrm{L}$ masih dalam konsentrasi yang belum membahayakan bagi kehidupan bakteri, tetapi hanya menghambat pembiakan bakteri tanpa membunuhnya.

Pada Gambar 2 terlihat bahwa populasi bakteri pada media NB pada hari ke tiga (D-3) setelah aplikasi untuk tiga jenis pestisida berfluktuasi, sedangkan pada hari ke-15 (D-15) setelah aplikasi populasi bakteri cenderung menurun aktivitasnya dibanding pada hari ke-3, 6, 9, dan 12. Menurunnya bakteri pada hari ke-15 diduga akibat reaksi pestisida telah berjalan lambat di samping itu juga disebabkan daya tahan bakteri Pseudomonas spp. yang sudah mulai menurun setelah lama berada di bawah pengaruh pestisida. Menurut Dwidjoseputro (1994), umumnya bakteri yang muda kurang daya tahannya terhadap desinfektan daripada bakteri yang tua.
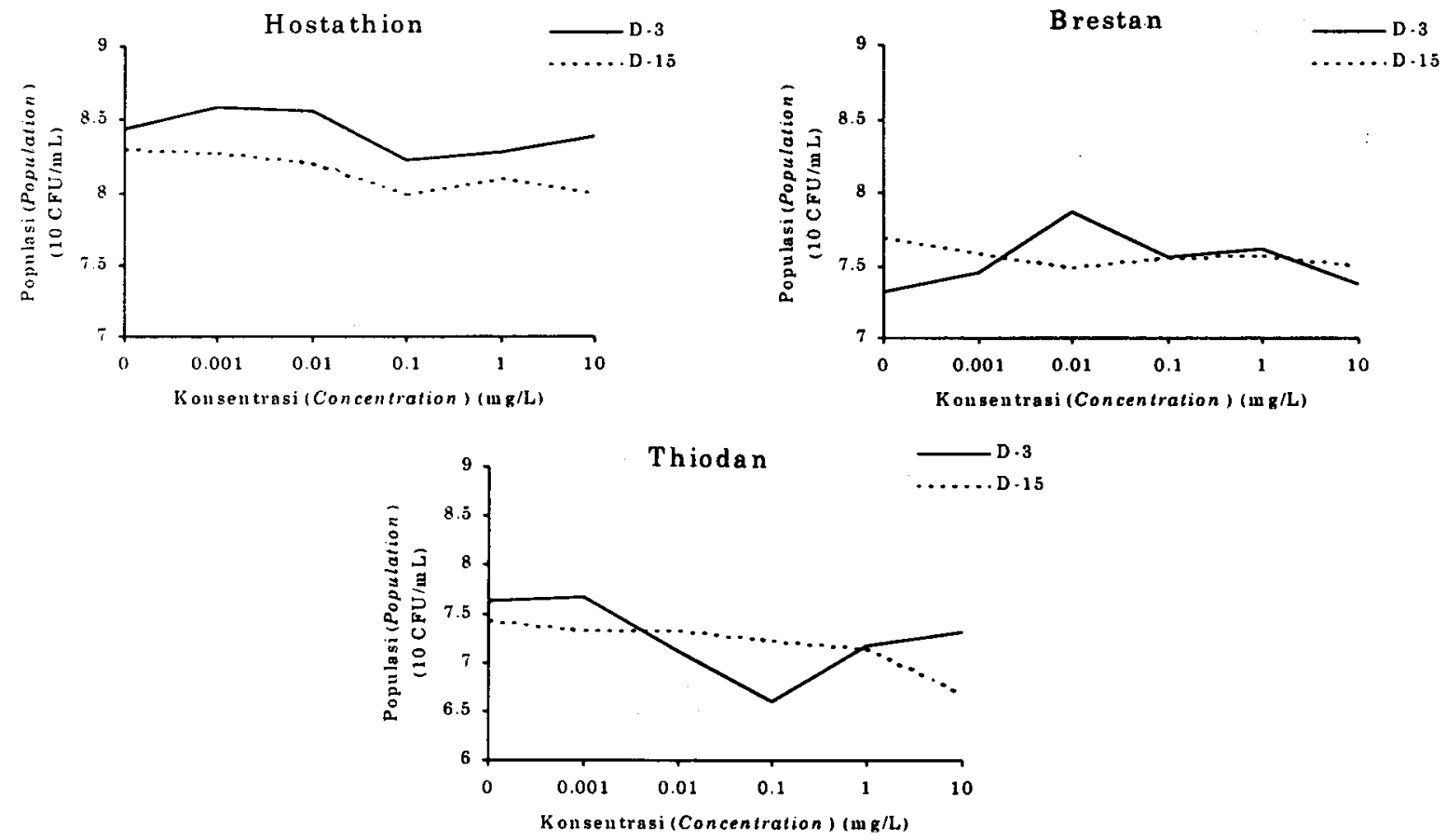

Gambar 2. Populasi bakteri Pseudomonas sp. setelah pada hari ke-3 dan 15 aplikasi pestisida pada media Nutrient Broth.

Figure 2. Population of bacteria Pseudomonas spp. after $d-3$ and $d-15$ day pesticide application on Nutrient Broth media. 
Pada media tanah, Brestan berpengaruh nyata $(P<0,05)$ pada hari ke-3, 6, 9, dan 15 serta berpengaruh tidak nyata $(P>0,05)$ pada hari ke.12 setelah inokulasi. Thiodan berpengaruh nyata $(\mathrm{P}<0,05)$ pada hari ke-3, 9, dan 12 dan berpengaruh tidak nyata $(P>0,05)$ pada hari ke.6 dan 15 , sedangkan Hostathion berpengaruh nyata $(P<0,05)$ pada hari ke-6, 9,12 , dan 15 , tetapi berpengaruh tidak nyata $(\mathrm{P}>0,05)$ pada hari ke-3 (Lampiran 3 ).

Jika dibandingkan pengaruh pestisida pada kedua media (NB dan tanah gambut), maka pengaruh pestisida kurang nyata terlihat terhadap populasi bakteri pada media Nutrient Broth, diduga bakteri Pseudomonas spp. yang telah diaplikasikan lebih menyukai habitat aslinya (tanah gambut) karena bakteri ini di isolasi dari tanah gambut, meskipun pada media TSA juga mengandung bahan yang diperlukan untuk pertumbuhan bakteri seperti pepton dan agar (Difco, 1984). Menurut Hanafi et al. (1997) bahwa tanah gambut mempunyai sumber bahan organik yang berasal dari serasah (sisa vegetasi) dan lambat laun bahan organik ini dapat melepaskan nitrogen. Selanjutnya N diperlukan oleh bakteri sebagai makanannya dan sebagai penyusun protoplasma untuk pertumbuhan dan berkembang biak (Suryati et al., 1996). Di samping itu unsur lain yang mempengaruhi aktivitas dan berkembang biaknya populasi sel mikroba adalah keseimbangan antara unsur hara makro yang ada di dalam tanah itu sendiri, misalnya sumber $C$ walaupun tidak dimanfaatkan secara utuh oleh mikroba namun sangat diperlukan oleh mikroba untuk sintasan dan berkembang biak bakteri sebagai akibat terbatasnya $\mathrm{N}$ (Compeau et al., 1988; Metting, 1993; Pantjara et al., 1997b).

Hasil penelitian Pantjara et al. (1998), adalah karena pestisida thiodan dapat mematikan udang $\mathrm{LC}_{30}(24 \mathrm{jam})$ pada konsentrasi $0,2673 \mathrm{mg} / \mathrm{L}$ dan $\mathrm{LC}_{100}(24$ jam) pada konsentrasi $1,0 \mathrm{mg} / \mathrm{L}$, namun tidak mematikan total bakteri di dalam tanah, tetapi hanya menurunkan populasi bakteri pada tanah gambut dari 1402,82.107 CFU/g bobot kering tanah pada awal penelitian dan menurun menjadi $675.10^{7}$ dan $53,27.10^{7} \mathrm{CFU} / \mathrm{g}$ bobot kering tanah, masing-masing pada konsentrasi 0,25 dan 10,0 $\mathrm{mg} / \mathrm{L}$ setelah empat hari aplikasi pestisida.
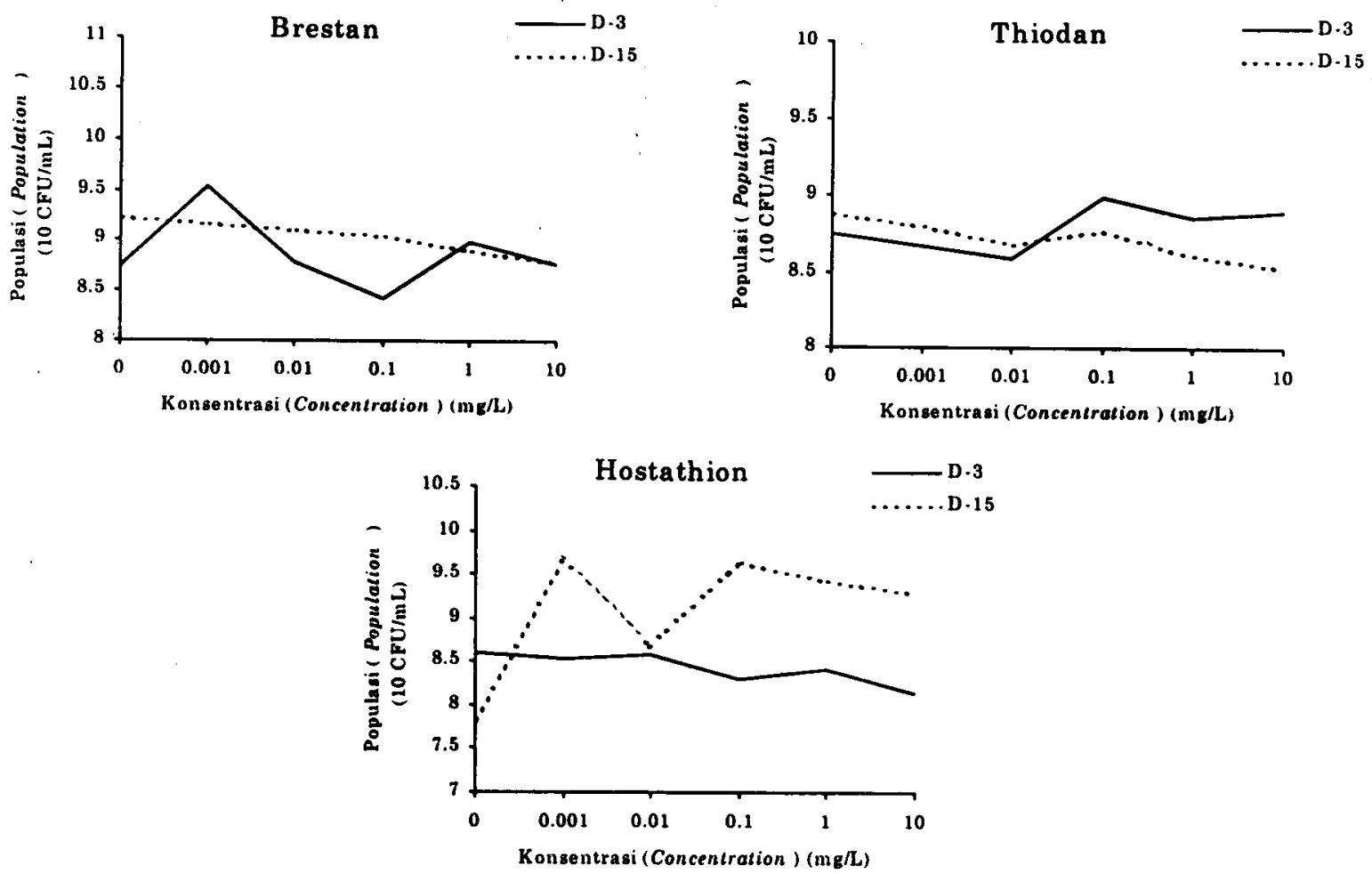

Gambar 3. Populasi bakteri Pseudomonas sp. pada hari ke-3 (D-3) dan 15 (D-15) setelah aplikasi pestisida pada tanah gambut.

Figure 3. Population of bacteria, Pseudomonas sp. at D-3 and D-15 after pesticide application in peat soil. 
Pengaruh pestisida (Brestan, Thiodan, dan Hostathion) terhadap bakteri Pseudomonas spp. pada media tanah gambut belum terlihat adanya kematian total terhadap bakteri, baik pada pengamatan hari ke-3 (D-3) maupun hari ke-15 (D15) setelah aplikasi pestisida (Gambar 3). Hal ini disebabkan konsentrasi pestisida yang dicobakan masih dalam batas yang belum mematikan bakteri tetapi hanya menghambat perkembangan bakteri. Menurut Dwidjoseputro (1994), bahwa pemberian desinfektan, germisida, dan bakterisida yang berlebihan dapat menghambat pembiakan bakteri bahkan dapat membunuh bakteri, sebaliknya pemberian zat kimia yang berasal dari desinfektan seperti fenol pada konsentrasi yang lebih rendah (encer) merupakan sumber tenaga (makanan) bakteri Pseudomonas spp.

Secara umum, tanah gambut sebelum aplikasi pestisida termasuk bereaksi masam, bahan organik dan rasio C:N tergolong tinggi. Pestisida yang diaplikasikan belum mempengaruhi kualitas tanah seperti $\mathrm{pH}$ dan potensial reduksi-oksidasi namun mempengaruhi bahan organik dan rasio $\mathrm{C}: \mathrm{N}$, yang ditunjukkan dengan terjadinya peningkatan bahan organik dan $\mathrm{N}$-total (Lampiran 4).

Potensial reduksi-oksidasi digunakan untuk mengetahui konsentrasi oksigen yang ada di dalam tanah. Potensial reduksi-oksidasi (redoks), sebelum dan sesudah aplikasi relatif stabil dan bernilai positif berkisar antara $+44 \mathrm{mV}$ hingga $+64 \mathrm{mV}$. Hal ini menunjukkan aerasi di dalam tanah masih berjalan baik. Menurut Stolp (1988), potensial reduksi-oksidasi antara $0 \mathrm{dan}+200 \mathrm{mV}$ biasanya dihuni bakteri microaerophilic.

Pada awal sebelum aplikasi pestisida $\mathrm{pH}$ tanah 5,87 , namun $\mathrm{pH}$ tanah berubah sesudah aplikasi sesuai dengan jenis pestisida. $\mathrm{pH}$ tanah cenderung menurun pada Brestan, relatif stabil pada Thiodan dan cenderung meningkat pada Hostathion. Proses penguraian bahan organik membutuhkan karbohidrat (C) sebagai sumber tenaga dan dalam perkembangannya juga membutuhkan unsur $\mathrm{N}$ untuk diasimilasikan menjadi penyusun tubuhnya. Hasil analisis sidik ragam pada ketiga jenis pestisida (Brestan, Thiodan dan Hostathion) menunjukkan pengaruh nyata $(P<0,05)$ terhadap bahan organik tanah, namun Brestan dan Hosthation tidak berpengaruh nyata $(P>0,05)$ terhadap kandungan $\mathrm{N}$ sedangkan Thiodan berpengaruh nyata $(P<0,05)$. Demikian juga terhadap kandungan karbon (C) Brestan tidak berpengaruh nyata $(P>0,05)$, tetapi Thiodan dan Hostathion berpengaruh nyata $(P<0,05)$. Hal ini menunjukkan bahwa sebenarnya terjadi penguraian bahan. bahan organik yang dicerminkan dengan mening. katnya $\mathrm{N}$-total, tetapi tampaknya juga terjadi penguraian serasah menjadi bahan organik yang lebih besar.

Menurut Foth (1991), penurunan kandungan bahan organik tanah secara umum disebabkan oleh peningkatan kegiatan mikroorganisme tanah. Namun dalam penelitian ini penurunan kandung. an bahan organik pada pestisida thiodan tidak seiring dengan peningkatan populasi bakteri Pseudomonas spp. Hal ini diduga penurunan kandungan bahan organik disebabkan oleh ter. jadinya proses penguraian bahan organik lebih cepat daripada perombakan bagian-bagian serasah.

\section{KESIMPULAN}

Pada konsentrasi > 0,01 mg/L Brestan mem. berikan daya hambat terhadap perkembangan Pseudomonas spp. pada media TSA, sedangkan Thiodan dan Hostathion memberikan daya hambat pada konsentrasi $>1,0 \mathrm{mg} / \mathrm{L}$.

Populasi Pseudomonas spp. baik pada media Nutrient Broth maupun tanah gambut cenderung menurun dengan kenaikan konsentrasi bahan pestisida yang diuji. Konsentrasi pestisida $10 \mathrm{mg} /$ L menurunkan populasi bakteri Pseudomonas spp. tetapi tidak mematikan secara total bakteri. Toksisitas tertinggi adalah Thiodan pada media Nutrient Broth dan Hostathion pada media tanah gambut.

\section{DAFTAR PUSTAKA}

Benson, H.J. 1985. Microbiological applications: A laboratory manual in genera microbiology. Fourth edition. Wm.C. Brown Publishers, Dubuque, Iowa.

Boyd, C.E. 1992. Shrimp pond bottom soil and sediment management. In J. Wyban(ed.), Proceedings of the Sp.ecial Session on Shrimp Farming. World Aquaculture Society, Baton Rouge, LA, USA. p. 43-58.

Compeau, G., B.J. Al-Achi, and E. Platsouka. 1988. Survival of rifamfin-resistant mutants of Pseudomonas fluorescent and Pseudomonas putida in soil systems. App. and Env. Microbiol. 54(10):2432-2438.

Dwidjoseputro, D. 1994. Dasar-dasar Mikrobiologi Penerbit Djambatan, Jakarta.

Difco. 1984. Difco Manual: Dehydrate culture media and reagents for microbiology. Tenth edition. Difco Laboratories, Detroit, Michican.

Foth, H. D. 1991. Dasar-dasar Ilmu Tanah. Edisi ke tujuh. Diterjemahkan oleh: E.D. Purbayanti, D.R 
Lukiwati, dan R. Trimulatsih, disunting oleh S.A.B. Hudoyo. Gadjah Mada University Press, Yogya. karta. 782 hal.

Garrett, S.D. 1981. Soil Fungi and Soil Fertility. Sec. ond edition. Pergamon Press, Oxford. New York. Toronto. Sydney, Paris, Frankfurt.

Gasperz, V. 1992. Metode Perancangan Percobaan. Institut Teknologi Bandung, Bandung.

Hanafi. A.. B. Pantjara, dan A. Tompo. 1995. Karakteristik partikel koloid pada tanah gambut. Laporan Hasil Penelitian. Balai Penelitian Perikanan Pantai. Maros.

Hanafi, A, T. Ahmad, and B. Pantjara. 1997. The utilization of coastal peat soil for fish culture as compo. nent of coastal resources management. TORANI 8:87.93.

Lay, B.W. 1994. Analisis Mikroba di Laboratorium. Raja Grafindo. Persada. Jakarta. 168 hal.

Metting. F.B. Jr. 1993. Structure and physiological ecol. ogy of soil microbial communities. In F.B. Metting. Jr. (ed). Soil microbial ecology: Application inagricultural and development management. Marcel Dekker. Inc.. New York, Basel, Hongkong. hal.3-25

Moriarty, D.J.W. 1987. Methodology for determining biomass and productivity of microorganisms in de. trital food webs. In D.J.W. Moriarty and R.S.V
Pullin (eds.), Detritus and microbial ecology in aquaculture. ICLARM, Manila. 4-31.

Pantjara, B., A. Hanafi, A. Mustafa, dan Muliani. 1997a. Karakterisasi mikroba pengurai bahan organik tambak tanah gambut. Laporan Hasil Penelitian Balai Penelitian Perikanan Pantai, Maros. 15 hal.

Pantjara, B, A. Mustafa, A. Hanafi dan M.I. Madeali. 1997b. Aplikasi TSP. dan peranan bakteri Micro. coccus terhadap perubahan bahan organik. Laporan Hasil Penelitian, Balai Penelitian Perikanan Pantai, Maros. 14 hal.

Pantjara, B.,A. Mustafa., A. Hanafi, dan Muliani. 1998. Pengaruh toksisitas pestisida pada tanah gambut terhadap sintasan udang. Laporan Hasil Penelitian, Balai Penelitian Perikanan Pantai, Maros. 12 hal.

Stolp. H. 1988. Microbial Ecology: organism, habitats, activities. Cambridge University. 308 pp.

Suryati. E. A. Hanafi. dan B. Pantjara. 1996. Peranan bakteri pengurai pada budidaya perikanan di tambak. Dalam Wiryowidagdo, S, P. Sudarmono. A. Subandrio. L. Muslimin. M. N. Djide, dan A.I Makhmud. Prosiding. Seminar Nasional Mikrobiologi Kelautan dan Bioremidiasi. Universitas Hasanudin, Ujung Pandang. hal. 185-187. 
Lampiran 1. Diameter hambatan $(\mathrm{mm})$ pestisida terhadap perkembangan bakteri Pseudomonas spp. dengan menggunakan media TSA.

Appendix 1. Inhibition diameter $(\mathrm{mm})$ of pesticide on the development of Pseudomonas spp. on TSA media.

\begin{tabular}{|c|c|c|c|c|c|c|c|}
\hline \multirow{2}{*}{$\begin{array}{c}\text { Konsentrasi } \\
\text { Concentration }\end{array}$} & \multicolumn{6}{|c|}{ Replikasi (Replication) } & \multirow{2}{*}{$\begin{array}{c}\text { Rata-rata } \\
\text { Average }\end{array}$} \\
\hline & 1 & 2 & 3 & 4 & 5 & 6 & \\
\hline \multicolumn{8}{|l|}{ A. Brestan } \\
\hline 10.0 & 18.05 & 16.05 & 18.45 & 21.95 & 15.80 & 22.42 & $18.79^{\mathrm{e}}$ \\
\hline 1.0 & 14.30 & 13.75 & 17.07 & 11.10 & 10.15 & 12.37 & $13.12^{\mathrm{d}}$ \\
\hline 0.1 & 8.90 & 8.40 & 8.03 & 9.10 & 8.03 & 10.08 & $8.76^{\mathrm{c}}$ \\
\hline 0.01 & 6.95 & 6.90 & 5.70 & 3.90 & 6.60 & 8.10 & $6.36^{\mathrm{b}}$ \\
\hline 0.001 & 0 & 0 & 0 & 0 & 0 & 0 & $0^{\mathrm{a}}$ \\
\hline 0.0001 & 0 & 0 & 0 & 0 & 0 & 0 & $0^{\mathrm{a}}$ \\
\hline Kontrol (Control) & 0 & 0 & 0 & 0 & 0 & 0 & $0^{\mathrm{a}}$ \\
\hline \multicolumn{8}{|l|}{ B. Thiodan } \\
\hline 10.0 & 2.30 & 3.30 & 3.90 & 6.05 & 5.30 & 6.60 & $4.58^{\mathrm{b}}$ \\
\hline 1.0 & 4.90 & 2.80 & 1.90 & 5.80 & 5.30 & 4.20 & $4.15^{\mathrm{b}}$ \\
\hline 0.1 & 0 & 0 & 0 & 0 & 0 & 0 & $0^{\mathrm{a}}$ \\
\hline 0.01 & 0 & 0 & 0 & 0 & 0 & 0 & $0^{\mathrm{a}}$ \\
\hline 0.001 & 0 & 0 & 0 & 0 & 0 & 0 & $0^{\mathrm{a}}$ \\
\hline 0.0001 & 0 & 0 & 0 & 0 & 0 & 0 & $0^{\mathrm{a}}$ \\
\hline Kontrol (Control) & 0 & 0 & 0 & 0 & 0 & 0 & $0^{\mathrm{a}}$ \\
\hline \multicolumn{8}{|l|}{ C. Hostathion } \\
\hline 10.0 & 9.80 & 8.40 & 8.90 & 9.30 & 9.30 & 13.70 & $9.90^{\mathrm{c}}$ \\
\hline 1.0 & 5.30 & 4.20 & 6.00 & 5.30 & 3.70 & 4.50 & $4.83^{b}$ \\
\hline 0.1 & 0 & 0 & 0 & 0 & 0 & 0 & $0^{\mathrm{a}}$ \\
\hline 0.01 & 0 & 0 & 0 & 0 & 0 & 0 & $0^{\mathrm{a}}$ \\
\hline 0.001 & 0 & 0 & 0 & 0 & 0 & 0 & $0^{\mathrm{a}}$ \\
\hline 0.0001 & 0 & 0 & 0 & 0 & 0 & 0 & $0^{\mathrm{a}}$ \\
\hline Kontrol (Control) & 0 & 0 & 0 & 0 & 0 & 0 & $0^{\text {a }}$ \\
\hline
\end{tabular}

Angka yang diikuti huruf tidak sama pada kolom yang sama berbeda nyata $(\mathrm{P}<0,05)$

Values in columns with the same superscript are significantly different $(P<0.05)$ 
Lampiran 2. Pengaruh pestisida terhadap populasi bakteri $\left(10^{6} \mathrm{CFU} / \mathrm{mL}\right)$ Pseudomonas spp. pada media Nutrient broth.

Appendix 2. Effect of pesticide on the population $\left(10^{6} \mathrm{CFU} / \mathrm{mL}\right)$ of Pseudomonas spp. of NB media.

\begin{tabular}{|c|c|c|c|c|c|c|}
\hline \multirow{2}{*}{$\begin{array}{c}\text { Konsentrasi } \\
\text { Concentration }\end{array}$} & & \multicolumn{5}{|c|}{$\begin{array}{l}\text { Pengamatan (hari) } \\
\text { Observation (day) }\end{array}$} \\
\hline & & 3 & 6 & 9 & 12 & 15 \\
\hline \multicolumn{7}{|l|}{ A. Brestan } \\
\hline Kontrol (Control) & & $21^{a}$ & $21^{a}$ & $89^{\mathrm{n}}$ & $7^{\text {ค }}$ & $49^{\text {a }}$ \\
\hline 0.001 & $\mathrm{mg} / \mathrm{L}$ & $28^{\text {ab }}$ & $42^{a}$ & $71^{\mathrm{a}}$ & $86^{\text {ab }}$ & $38^{\text {a }}$ \\
\hline 0.01 & $\mathrm{mg} / \mathrm{L}$ & $73^{d}$ & $281^{b}$ & $117^{\circ}$ & $278^{\mathrm{abc}}$ & $31^{\mathrm{a}}$ \\
\hline 0.1 & $\mathrm{mg} / \mathrm{L}$ & $36^{\mathrm{lc}}$ & $152^{a b}$ & $201^{\text {ab }}$ & $148^{\text {abc }}$ & $36^{\mathrm{a}}$ \\
\hline 1.0 & $\mathrm{mg} / \mathrm{L}$ & $41^{c}$ & $126^{\text {ab }}$ & $303^{\mathrm{ab}}$ & $114^{\mathrm{be}}$ & $37^{\mathrm{a}}$ \\
\hline 10.0 & $\mathrm{mg} / \mathrm{L}$ & $24^{n}$ & $156^{\mathrm{nb}}$ & $94^{*}$ & $253^{c}$ & $32^{n}$ \\
\hline \multicolumn{7}{|l|}{ B. Thiodan } \\
\hline Kontrol (Control) & & $43^{\text {al) }}$ & $12^{a}$ & $18^{\mathrm{a}}$ & $16^{\mathrm{ab}}$ & $27^{b}$ \\
\hline 0.001 & $\mathbf{m g} / \mathbf{L}$ & $47^{\mathrm{b}}$ & $29^{a}$ & $4^{n}$ & $17^{\text {ab }}$ & $22^{\text {ab }}$ \\
\hline 0.01 & $\mathbf{m g} / \mathbf{L}$ & $13^{\text {ab }}$ & $29^{a}$ & $15^{a}$ & $25^{\mathrm{Ab}}$ & $22^{\mathrm{ab}}$ \\
\hline 0.1 & mg/L & $4^{\prime \prime}$ & $27^{a}$ & $16^{\mathrm{n}}$ & $52^{\prime}$ & $17^{\text {at }}$ \\
\hline 1.0 & $\mathrm{mg} / \mathrm{L}$ & $15^{\text {nls }}$ & $31^{n}$ & $10^{a}$ & $17^{\mathrm{ab}}$ & $14^{\mathrm{ab}}$ \\
\hline 10.0 & $\mathrm{mg} / \mathrm{L}$ & $21^{\mathrm{nb}}$ & $24^{a}$ & $12^{\mathrm{a}}$ & $6^{a}$ & $5^{a}$ \\
\hline \multicolumn{7}{|l|}{ C. Hosthation } \\
\hline Kontrol (Control) & & $267^{\text {Alx }}$ & $274^{\mathrm{a}}$ & $197^{\mathrm{A}}$ & $298^{b c}$ & $199^{b}$ \\
\hline 0.001 & $\mathrm{mg} / \mathrm{L}$ & $392^{\circ}$ & $184^{\mathrm{a}}$ & $144^{\mathrm{a}}$ & $385^{c}$ & $189^{b}$ \\
\hline 0.01 & mg/L & $361^{\ln }$ & $267^{\mathrm{a}}$ & $209^{n}$ & $202^{\mathrm{ab}}$ & $162^{\mathrm{nb}}$ \\
\hline 0.1 & $\mathrm{mg} / \mathrm{L}$ & $168^{n}$ & $120^{\mathrm{a}}$ & $107^{\mathrm{a}}$ & $98^{\mathrm{A}}$ & $127^{\mathrm{ab}}$ \\
\hline 10.0 & $\mathbf{m g} / \mathbf{L}$ & $241^{\mathrm{gbc}}$ & $141^{\mathrm{B}}$ & $217^{a}$ & $121^{n}$ & $99^{a}$ \\
\hline
\end{tabular}

Angka yang diikuti huruf tidak sama pada kolom yang sama berbeda nyata $(P<0.05)$

Values in columns with the same superscript are significantly different $(P<0.05)$ 
Lampiran 3. Pengaruh Pestisida terhadap populasi bakteri $\left(10^{6} \mathrm{CFU} / \mathrm{g}\right)$ Pseudomonas spp. dengan menggunakan media tanah gambut.

Appendix 3. Effect of pesticide on the population $\left(10^{6} \mathrm{CFU} / \mathrm{g}\right)$ Pseudomonas spp. of peat soil media.

\begin{tabular}{|c|c|c|c|c|c|c|}
\hline \multirow{2}{*}{$\begin{array}{l}\text { Konsentrasi } \\
\text { Concentration }\end{array}$} & & \multicolumn{5}{|c|}{$\begin{array}{c}\text { Pengamatan (hari) } \\
\text { Observation (day) }\end{array}$} \\
\hline & & 3 & 6 & 9 & 12 & 15 \\
\hline \multicolumn{7}{|l|}{ A. Brestan } \\
\hline Kontrol (Control) & & $559^{\mathrm{ab}}$ & $354,2^{b}$ & $2,934^{b}$ & 1,559 औ & $1,675^{d}$ \\
\hline 0.001 & $\mathbf{m g} / \mathbf{L}$ & $3,377^{c}$ & $3,538^{b}$ & $3,679^{c}$ & 1,289 & $1,478^{\mathrm{cd}}$ \\
\hline 0.01 & $\mathrm{mg} / \mathrm{L}$ & $620^{d}$ & $510^{\mathrm{a}}$ & $838^{a}$ & $1,449^{\text {a }}$ & $1,275^{\text {bed }}$ \\
\hline 0.1 & $\mathrm{mg} / \mathrm{L}$ & $265^{\mathrm{ab}}$ & $854^{\mathrm{a}}$ & $904^{\mathrm{a}}$ & $1,040^{\text {a }}$ & $1,125^{\mathrm{abc}}$ \\
\hline 1.0 & $\mathrm{mg} / \mathrm{L}$ & $992^{b}$ & $1,321^{\mathrm{a}}$ & $1,226^{\mathrm{ab}}$ & 715 & $823^{\text {ab }}$ \\
\hline 10.0 & $\mathbf{m g} / \mathrm{L}$ & $589^{\mathrm{ab}}$ & $950^{a}$ & $741^{a}$ & $653^{n}$ & $620^{\prime}$ \\
\hline \multicolumn{7}{|l|}{ B. Thiodan } \\
\hline Kontrol (Control) & & $294^{\mathrm{a}}$ & $731^{\mathrm{a}}$ & $347^{\mathrm{ab}}$ & $714^{\mathrm{ab}}$ & $766^{b}$ \\
\hline 0.001 & $\mathbf{m g} / \mathrm{L}$ & $455^{\mathrm{alb}}$ & $554^{\mathrm{a}}$ & $301^{\mathrm{ab}}$ & $316^{\mathrm{a}}$ & $635^{a}$ \\
\hline 0.01 & $\mathrm{mg} / \mathrm{L}$ & $389^{\mathrm{ab}}$ & $269^{a}$ & 260 & $733^{\mathrm{ab}}$ & $478^{n}$ \\
\hline 0.1 & $\mathrm{mg} / \mathrm{L}$ & $985^{b}$ & $1,023^{a}$ & $985^{b}$ & $405^{a b}$ & $589^{a}$ \\
\hline 1.0 & $\mathrm{mg} / \mathrm{L}$ & $701^{\text {ab }}$ & $1,030^{\mathrm{a}}$ & $218^{A}$ & $866^{b}$ & $417^{n}$ \\
\hline 10.0 & $\mathbf{m g} / \mathbf{L}$ & $781^{\text {ab }}$ & $720^{\text {a }}$ & $456^{\mathrm{ab}}$ & $394^{\mathrm{ab}}$ & $337^{\wedge}$ \\
\hline \multicolumn{7}{|l|}{ C. Hosthation } \\
\hline Kontrol (Control) & & $393^{a}$ & $660^{b c}$ & $335^{b}$ & $886^{c}$ & $642^{b}$ \\
\hline 0.001 & $\mathrm{mg} / \mathrm{L}$ & $333^{8}$ & $561^{\text {ab }}$ & $334^{b}$ & $547^{\mathrm{ab}}$ & $488^{\mathrm{ab}}$ \\
\hline 0.01 & $\mathrm{mg} / \mathrm{L}$ & $372^{a}$ & $422^{n}$ & $177^{a}$ & $544^{\mathrm{ab}}$ & $467^{\mathrm{ab}}$ \\
\hline 0.1 & $\mathbf{m g} / \mathbf{L}$ & $197^{\mathrm{a}}$ & $705^{c}$ & $238^{\text {ab }}$ & $734^{\mathrm{bc}}$ & $435^{\mathrm{ab}}$ \\
\hline 1.0 & $\mathrm{mg} / \mathrm{L}$ & $264^{n}$ & $451^{\text {sb }}$ & $280^{\mathrm{ab}}$ & $664^{\mathrm{bc}}$ & $276^{\text {* }}$ \\
\hline 10.0 & $\mathrm{mg} / \mathrm{L}$ & $137^{\mathrm{a}}$ & $330^{a}$ & $343^{b}$ & $339^{\circ}$ & $200^{\mathrm{a}}$ \\
\hline
\end{tabular}

Angka yang diikuti huruf tidak sama pada kolom yang sama berbeda nyata $(\mathrm{P}<0,05)$

Values in columns with the same superscript are significantly different $(P<0.05)$ 
Lampiran 4. Pengaruh pestisida dan peranan bakteri Pseudomonas spp. terhadap kualitas tanah gambut.

Appendix 4. Effect of pesticide and the role of Pseudomonas spp. on the quality of peat soil.

\begin{tabular}{|c|c|c|c|c|c|c|c|c|}
\hline \multirow{2}{*}{$\begin{array}{c}\text { Konsentrasi } \\
\text { Concentration }\end{array}$} & & \multicolumn{2}{|c|}{ pH } & \multirow{2}{*}{$\begin{array}{c}\text { Potensi } \\
\text { redoks } \\
\text { Redox } \\
\text { potential } \\
\text { (mV) }\end{array}$} & \multirow{2}{*}{$\begin{array}{c}\text { Bahan } \\
\text { organik } \\
\text { Organic } \\
\text { matter } \\
(\%)\end{array}$} & \multirow{2}{*}{$\begin{array}{l}\mathrm{C} \\
(\%)\end{array}$} & \multirow{2}{*}{$\begin{array}{c}\text { N-total } \\
(\%) \\
\end{array}$} & \multirow{2}{*}{$\begin{array}{l}\mathbf{C} / \mathbf{N} \\
(\%)\end{array}$} \\
\hline & & $\mathbf{K C l}$ & $\mathrm{H}_{8} \mathrm{O}$ & & & & & \\
\hline "Awal (Initial) & & 5.87 & 6.04 & +51 & 15.93 & 9.24 & 0.46 & 20.09 \\
\hline \multicolumn{9}{|c|}{$\begin{array}{l}\text { "Setelah pemakaian pestisida } \\
\text { (After application of pesticide) }\end{array}$} \\
\hline \multicolumn{9}{|l|}{ A. Brestan } \\
\hline Kontrol (Control) & & 5.85 & 5.90 & +58 & $16.83^{\mathrm{ab}}$ & $9.76^{\mathrm{a}}$ & $0.54^{a}$ & $18.07^{\mathrm{a}}$ \\
\hline 0.001 & $\mathrm{mg} / \mathrm{L}$ & 5.79 & 5.95 & +55 & $17.28^{b}$ & $10.02^{a}$ & $0.48^{a}$ & $20.87^{c}$ \\
\hline 0.01 & $\mathbf{m g} / \mathbf{L}$ & 5.74 & 6.00 & +52 & $17.74^{b}$ & $10.29^{\mathrm{a}}$ & $0.42^{\mathrm{n}}$ & $24.50^{d}$ \\
\hline 0.1 & $\mathrm{mg} / \mathrm{L}$ & 5.84 & 5.93 & +56 & $15.11^{\mathrm{a}}$ & $8.76^{\mathrm{a}}$ & $0.51^{n}$ & $17.18^{\mathrm{a}}$ \\
\hline 1.0 & $\mathrm{mg} / \mathrm{L}$ & 5.71 & 5.93 & +56 & $16.44^{\mathrm{ab}}$ & $9.54^{\mathrm{a}}$ & $0.46^{\mathrm{a}}$ & $20.74^{\mathrm{c}}$ \\
\hline 10.0 & $\mathrm{mg} / \mathrm{L}$ & 5.75 & 5.80 & +64 & $18.13^{\mathrm{b}}$ & $10.52^{\mathrm{b}}$ & $0.55^{\mathrm{a}}$ & $19.13^{\mathrm{bc}}$ \\
\hline \multicolumn{9}{|l|}{ B. Thiodan } \\
\hline Kontrol (Control) & & 5.77 & 6.10 & +44 & $17.51^{d}$ & $10.16^{\mathrm{c}}$ & $0.37^{\mathrm{a}}$ & $27.46^{\mathrm{l}}$ \\
\hline 0.001 & $\mathrm{mg} / \mathrm{L}$ & 5.90 & 6.07 & +46 & $13.81^{\mathrm{c}}$ & $8.01^{\mathrm{b}}$ & $0.44^{\mathrm{ab}}$ & $18.2^{d}$ \\
\hline 0.01 & $\mathrm{mg} / \mathrm{L}$ & 6.04 & 6.05 & +49 & $10.11^{\mathrm{a}}$ & $5.86^{\mathrm{a}}$ & $0.51^{\mathrm{ab}}$ & $11.49^{\mathrm{a}}$ \\
\hline 0.1 & $\mathrm{mg} / \mathrm{L}$ & 5.91 & 6.03 & +50 & $12.78^{\mathrm{lcc}}$ & $7.41^{\mathrm{ab}}$ & $0.55^{b}$ & $13.47^{\mathrm{b}}$ \\
\hline 1.0 & $\mathrm{mg} / \mathrm{L}$ & 5.88 & 6.04 & +49 & $11.18^{\mathrm{ab}}$ & $6.48^{\mathrm{ab}}$ & $0.41^{\mathrm{ab}}$ & $15.80^{e}$ \\
\hline 10.0 & $\mathrm{mg} / \mathrm{L}$ & 5.68 & 6.01 & +51 & $16.89^{d}$ & $9.80^{\mathrm{c}}$ & $0.40^{\mathrm{ab}}$ & $24.5^{\mathrm{e}}$ \\
\hline \multicolumn{9}{|l|}{ C. Hosthation } \\
\hline Kontrol (Control) & & 5.88 & 6.14 & +51 & $17.0^{\mathrm{a}}$ & $9.86^{\mathrm{a}}$ & $0.46^{\mathrm{a}}$ & $21.43^{\mathrm{ab}}$ \\
\hline 0.001 & $\mathrm{mg} / \mathrm{L}$ & 5.89 & 6.14 & +51 & $18.41^{\mathrm{ab}}$ & $10.68^{\mathrm{a}}$ & $0.48^{\mathrm{a}}$ & $22.25^{\text {ab }}$ \\
\hline 0.01 & $\mathbf{m g} / \mathbf{L}$ & 5.91 & 6.14 & +52 & $19.83 b$ & $11.50^{\mathrm{ab}}$ & $0.51^{\mathrm{a}}$ & $22.55^{\mathrm{ab}}$ \\
\hline 0.1 & $\mathrm{mg} / \mathrm{L}$ & 5.90 & 6.08 & +55 & $18.54^{\mathrm{ab}}$ & $10.75^{\mathrm{a}}$ & $0.55^{a}$ & $19.54^{\mathrm{a}}$ \\
\hline 1.0 & $\mathrm{mg} / \mathrm{L}$ & 5.86 & 6.13 & +52 & $19.67^{b}$ & $11.41^{\mathrm{ab}}$ & $0.46^{\mathrm{a}}$ & $24.80^{\mathrm{b}}$ \\
\hline 10.0 & $\mathrm{mg} / \mathrm{L}$ & 6.17 & 6.25 & +44 & $21.90^{\mathrm{c}}$ & $12.7^{\mathrm{b}}$ & $0.46^{\mathrm{a}}$ & $27.61^{\mathrm{c}}$ \\
\hline
\end{tabular}

Angka yang diikuti huruf tidak sama pada kolom yang sama berbeda nyata $(\mathrm{P}<0,05)$

Values in columns with the same superscript are significantly different $(P<0.05)$ 